The Douglas-fir/White Spirea Habitat Type in Central Idaho: Succession and Management. 1994. Robert Steele and Kathleen Geier Hayes. Gen. Tech. Rep. INT-GTR-305. Ogden, UT: US Department of Agriculture, Forest Service, Intermountain Research Station. 81 p.

Uses and Abuses of Multipliers in the Stand Prognosis Model. 1994. David A. Hamilton, Jr. Gen. Tech. Rep. INTGTR-310. Ogden, UT: U.S. Department of Agriculture, Forest Service, Intermountain Research Station. 9 p.

Georgia's Timber Industry: An Assessment of Timber Product Output and Use. 1992. 1994. Tony G. Johnson. Resour. Bull. SE-144. Asheville, NC: US Department of Agriculture, Forest Service, Southeastern Forest Experiment Station. 32 p.

Ten-year Effect of Six-site Preparation Treatments on Piedmont Loblolly Pine Survival and Growth. 1994. M. Boyd Edwards. Res. Pap. SE-288. Asheville, NC: U.S. Department of Agriculture, Forest Service, Southeastern Forest Experiment Station. 10 pp.

How to Identify Ozone Injury on Eastern Forest Bioindicator Plants. 1994. Elizabeth A. Brantley, Robert L. Anderson, and Gretchen Smith. Prot. Rep. R8-PR 25. U.S. Department of Agriculture, Forest Service, Atlanta, GA. 9 p. Pamphlet.

Annotated Bibliography of Publications on Watershed Management and Ecological Studies at Coweeta Hydrologic Laboratory, 1993-1994. 1994. Patricia L. Stickney, Lloyd W. Swift, and Wayne T. Swank, comps. Gen. Tech. Rep. SE-86. Asheville, NC: U.S. Department of Agriculture, Forest Service, Southeastern Forest Experiment Station. 115 p.

Dividends from Wood Research, Recent Publications, January-June 1994. Forest Products Laboratory, U.S. Forest Service, One Gifford Pinchot Drive, Madison, Wisconsin 53705-2398.

Forest cover from Landsat Thematic Mapper Data for use in the Catahoula Ranger District Geographic Information System. 1994. David L. Evans. Gen. Tech. Rep. SO-99. New Orleans, LA: U.S.

\title{
Book News and Reviews
}

The Last Great Forest - Japanese Multinationals and Alberta's Northern Forests. Pratt, Larry and Ian Urquhart, NeWest Press, Edmonton, Alberta, Canada. 222 pp., 1994. ISBN 0-92089777-0.

The Last Great Forest is "a western Canadian version of the conflict taking place in the American West, a conflict between an older resource extractive economy and a new environmental economy... It examines the political conflict between the visions of multinational pulp and paper companies and their allies in government on one hand and those of Natives and environmental on the other hand". However, for all its pretenses, it is the views of two environmentalists

Department of Agriculture, Forest Service, Southern Forest Experiment Station. $14 \mathrm{p}$.

Proceedings of the 1992 Southern Regional Information Exchange Group (SRIEG) Biennial Symposium on Forest Genetics: 1992 July 8-10; Huntsville, AL. 1994. G. Sam Foster and Alex M. Diner. Gen. Tech. Rep. SO108. New Orleans, LA: U.S. Department of Agriculture, Forest Service, Southern Forest Experiment Station. 152 p.

Impact of In-woods Product Merchandizing on Profitable Logging Opportunities in Southern Upland Hardwood Forests. Denis M. May, Chris B. LeDoux, John B. Tansey and Richard Widmann. Res. Pap. SO-282. New Orleans, LA: U.S. Department of Agriculture, Forest Service, Southern Experiment Station. 11 p.

Proceedings of the Symposium on Ecosystem Management Research in the Ouachita Mountains: Pretreatment Conditions and Preliminary Findings, 1993 October 26-27; Hot Springs, AR. 1994. James Baker, comp. Gen. Tech. Rep. SO-112. New Orleans, LA: U.S. Department of Agriculture, Forest Service, Southern Forest Experiment Station. $259 \mathrm{p}$. on forestry developments in Alberta, Canada. Most specifically, it is about how the Alberta Government awarded Forest Management Agreement Areas to Daishowa Canada, eventually to be named Daishowa-Marubeni International (DMI), and Alberta-Pacific Forest Industries Inc. (ALPAC).

It is not easy to write a history book, and it is even more difficult to write one that is objective. This is true for many reasons. First, not everything is as it appears and most authors lack all of the information necessary to fully explain what actually caused the outcomes observed. This is particularly true when the best information sources available are printed materials or official statements. Second, by necessity all histories must be limited in scope. This book described well the views of individuals in the environmental movement but little space is devoted to the views of northern residents in need of jobs.

Also, it failed to describe the significance of other sources of pollution such as farming or community development, which are common along the water systems to be affected by these developments. Third, the authors dedicated very little text to the environmental and social costs of other alternatives available for achieving economic stability in these northern areas. Last, all of us suffer from personal biases and these attitudes are commonly found in our writings. The authors failed to appreciate these limitations, hence the difficulty in accomplishing their goal.

This history was developed from many newspaper articles, press releases, news conferences, public hearing transcripts, personal interviews, private letters, trade journal articles and some published literature. A great deal of energy was devoted to uncovering information. However, at the time of these developments, most printed and spoken information pertaining to these projects fell into two categories; those from government and industry sources that supported initiatives and those from environmental groups and the government opposition, which opposed it. Based on information provided in this book few non-government and nonindustry sources supported these developments, even though during this period many articles were published in the 
Edmonton Journal, a newspaper that served as an important information source for this book. Arguments from individuals who campaign strongly against these developments carried substantially more weight than the opinions of northern municipal councils, development boards, and even some native groups, who supported these initiatives. There was a bias against development that pervaded this outline of events and unfortunately this one-sided interpretation will be preserved through time as a result of this publication.

From a literary perspective, the book was not an easy read. Sentences frequently exceeded 40 words in length, with the record being 112-116 words depending on how one counts the four hyphened words in that sentence. As for the storyline, at times the interjections of minor but clarifying stories were out of sequence, yet the full dates are not provided, so at times it is difficult to keep track of what happened when. There was liberal use of parenthetical phrases.

In closing, this book deserves a place in the history of forest development in Alberta or Canada if for no other reason than it stands as a permanent record of views held by many individuals in this Province and elsewhere. These views are real and important, and these individuals have the power to make choices that may not be in society's best interest. In addition, foresters in Alberta, particularly, must always remember that most of the forested land in this Province belongs to the people and they have the right to decide what happens on it. For these reasons and more, they deserve the attention and the cooperation of the foresters and the forest industry operating in this Last Great Forest.

Paul M. Woodard University of Alberta
Tropical Rainforests: Latin America Nature and Society in Transition. 1993. Susan E. Place, Editor. Jaguar Books on Latin America, Number 2. Scholarly Resources Inc., 104 Greenhill Avenue, Wilmington, Delaware 198051897. USA 222 pages. Cloth ISBN 0-8420-2439-9. \$40.00; Paper ISBN 0-8420-2427-1, \$14.95.

This book provides a selection of readings dealing with the tropical rainforest of Latin America. It is divided into four parts. I. Perceptions of the Rainforest, II Explanations for Deforestation in Latin America, III Why Save the Rainforests?, and IV Prospects for Development: Alternative Futures for the Rainforest.

The editor, Susan Place, an associate professor of geography at California State University at Chico, has included thirty essays dealing with tropical deforestation. The articles have been written by economists, naturalists, anthropologists, and historians, and reflect the complexity of the topic.

Part I, Perceptions of the Rainforest, presents five items, dealing with such topics as the exploitation of man and nature in the Amazon basin, a naturalists view of the Amazon, environmental limitations on culture in the tropical forest and the Indians of Amazonia.

Part II discusses Explanations for Deforestation in Latin America including the development of a global antimalaria campaign and a yellow fever vaccine which permitted the settlement of forested hinterlands as well as a population explosion, the impact of cattle raising (which has slowed in recent years), road building, oil and gas exploration, and the militarization and industrialization of Amazonia.

Part III, Why Save the Rainforests?, provides a plan for action to preserve the rainforest and emphasizes its importance for bio- diversity, in regulating droughts and floods, in moderating climatic change and in providing a variety of foods and medicines.

Part IV, Prospects for Development: Alternative Futures for the Rainforest, explores some of the various attempts to find a path to sustainable development. The editor notes that "In tropical rainforest regions, sustainable development entails preservation of some mature forest while encouraging ecologically sound exploitation and management of other forested areas. Inevitably, some areas will be converted to other uses entirely. The challenge is to identify the appropriate mix of land uses for the remaining rainforest regions." Alternatives for preserving the rainforest include legal protection from commercial exploitation through the establishment of national parks, development of ecotourism, and preservation of forests as extractive reserves for such renewable commodities as latex, Brazil nuts, palm and resin or for pharmaceuticals. One selection focuses on sustainable timber production and discusses plantation forestry, tropical agriculture and agro-forestry, and natural forest management as three basic strategies that might link economic development and conservation objectives.

While the book is interesting and easy to read, the reader is left entirely in the hands of the editor for coverage of the topic. Essays have apparently been selected to fit with the editor's views, rather than to present a balanced view. All development seems to have been viewed as bad, little is considered to have been positive. In most cases the authors of the individual essays are inadequately introduced; it appears as if no professional foresters have been included among the authors. While the book is technically well laid out, it lacks an index, has no photographs, and only two very generalized maps.

J.H. Cayford, R.P.F.

Forests: The Shadow of Civilization. Robert Pogue Harrison. The University of Chicago Press, Chicago. 1992. 288 pp. \$24.95. ISBN 0-226-31807-9.

Rarely does a book attempt to interpret Western Civilization's relationship with the wilderness and forests through an examination of its myths and fables. Yet in this compelling analysis of both our domination of, and alienation from, the natural world, Robert Harrison has set out to provide insights into humankind's 
ties to the forest with reference to legends from both classical and modern literature. Virgil, Dante, Gilgamesh, Dionysus, Descartes, Rousseau, Conrad, Wordsworth, and many other voices are culled to construct a cultural history in Forests: The Shadow of Civilization that blends, history, philosophy, literature and science.

The story unfolded in these pages will sound familiar to all, one of massive destruction as humanity cleared the ancient woodland for its ordered fields and productive towns, the forests seen as wild and lawless recesses of dangerous and unpredictable obstacles. Then, over thousands of years, a gradual development of the perception of the forest as a place where the individual might find peace and serenity, coupled with increasing efforts to conserve and manage the wilderness that remained.

Nor, therefore, will Harrison's conclusions come as much of a surprise. He contends that the forest exists as a magical and frightening place, something with its own life both to be overcome yet preserved: simultaneously essential to society's spiritual health and obstacle to be mastered and domesticated. But the manner in which Harrison arrives at this interpretation, starting with a passage from the Aeneid, where the future birth site of Rome is the home of a mighty woodland, and finishing with Austrian poet Georg Trakl, who compares death with returning to the forest, is original, exciting, and evocative.

This book may not be for many. Most of the legends examined are obscure and fanciful, and few nowadays are familiar with the works cited. Forests is a gift of literature as much as it is work of history, and Harrison's style of writing is probably best suited to academics. Yet, if one is willing to permit their imagination to be their guide, at the end readers may find that they have an increased understanding, with a far different perception than the day-to-day, of the relationship between humanity and the forest, and the reasons for our continual return to it as a source of spiritual renewal.

(Robert Pogue Harrison is a professor of French and Italian literature at Stanford University. Other publications include: The Body of Beatrice, Comedy and Modernity: Dante's Hell, The Italian Silence.)

Michael Haynes Sport Nova Scotia
Environmental Accounting for the Sustainable Corporation: Strategies and Techniques by Daniel Blake Rubenstein.

Covers the essentials of the theory and practice of this newly emerging field. Rubenstein, a principal in the Office of the Auditor General in Canada, based his book on a research project he recently completed for the United Nations. He uses a fictionalized case study based on the real experiences of an integrated forest management company to propose a new methodology for computing fuller costs at the corporate level. In a readable, straightforward style, Rubenstein tackles such topics as defining sustainable entities, intergenerational equity, and the application of risk-management principles to costing natural capital. The book is available for US \$55 from Quorum Books, 88 Post Road West, P.O. Box 5007, Westport, CT 06881-5007, USA. Tel: +1 203226 3571; Fax: +1 2032221502.

Science Report 1992/93. New Zealand Forest Research Institute Ltd., Rotorua, 40 p., undated, unpriced, ISSN 1172 7837.

Established in 1947, the New Zealand Forest Research Institute earned an enviable reputation for excellence during the first 45 years of its existence. In July 1992, the institute became New Zealand Forest Research Institute Limited, a Crown Research Institute, governed by a Board of Directors accountable for the financial performance of the company. How this will affect forest and forestry research in New Zealand remains to be seen, but the buzzword barrage that emanates from the Executive Report is not entirely encouraging: "challenging", "exciting", "restructuring", "dynamic", "innovative strategies", "linkages and partnerships", etc. And, while "integration at key points of interface in the value chai..." may enlighten some people, others, including your reviewer, will be puzzled. One wonders whether "The immediate challenge is for the organization to develop sufficient investment capability to foster new and novel research, creativity, and leading edge technology development" really means "We're short of money." However, the statement that "The year has been particularly challenging for NZ FRI employees..." is not difficult to interpret.

The new company in its first year "met its obligations under the Crown Research Institutes Act 1992"; $41.5 \%$ of revenue was earned from commercial sources.

Among many items of interest covered in the Review mention may be made of:

- Results of field trials on four farm and four forest sites comparing seedlings, cuttings, and tissue-cultured plantlets (presumably radiata pine), indicate that vegetatively propagated stock types will perform as well as, or better than, conventional seedlings.

- New results implicate the significance of genetics in nutrition and susceptibility to nutrient-related stresses in radiata pine.

- The relationship between plant nutrient status and pre-visual symptoms of stress as detected by remotely sensed spectral reflectance is being investigated in collaboration with the University of Georgia and the Stenos Space Center in Mississippi. - The use of GIS in the forestry industry is increasing rapidly and NZ FRI supports a Canadian-developed PC-based GIS, TERRA, which is gaining increased use by land management agencies in New Zealand.

- The Plantation Management Group continued to establish and maintain longterm trials of radiata pine and Douglasfir on a wide range of sites and under a variety of silvicultural treatments.

- Topsoils in conifer plantations "invariably" contained higher levels of available nutrients than did grassland topsoils.

- To investigate the response of trees to future climatic conditions, 16 open-top containers, each $3.6 \mathrm{~m}$ tall and $4.7 \mathrm{~m}$ in

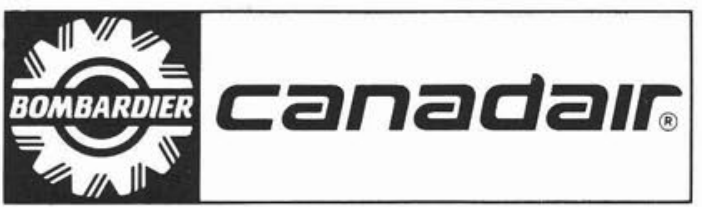

A CIF/IFC Corporate Sustaining Member 
diameter, have been set up in the field to monitor the uptake and storage of carbon by clonal radiata pine and red beech growing at ambient and elevated carbon dioxide concentrations and elevated temperatures.

- An evaluation of the physiological workload of forestry workers and loggers found that motor manual felling and delimbing produced an average rate of 127 heart beats per minute compared with 70 beats per minute for operators of "fellerdirectors" clearfelling radiata pine.

- Studies using the Remote Tension Monitoring device found that skyline tensions developed by 12 of 14 machines exceeded safe working limits, some by as much as $50 \%$.

- Studies have documented the strong tendency for wood from younger stands to warp unless high temperature drying with mechanical restraint is used. Even the best drying methods cannot guarantee a degrade-free product from young wood.

- A moisture-resistant adhesive system, Greenweld, permitting green wood to be glued, has been developed and is now commercially applied in New Zealand. - Use of radiata pine market kraft pulps in blends with hardwoods have produced high quality printing and writing papers equivalent to those made using the "highly regarded Canadian softwood pulps" as the reinforcing component of the furnish.

The Report lists publications produced by the six science divisions: Biotechnology, Forest Technology, Logging Industry Research Organisation, Wood Processing, Wood Products, and Pulp and Paper Research Organisation. A diagram of the operating structure is given, but, in contrast with former FRI Annual Reports, staff are not listed. Visually, the Report is as attractive as ever. Sadly, the same cannot be said of its content.

R.F. Sutton

Trees \& People: Forestland Ecosystems and Our Future. Richard N. Jordan, Regnery Publishing, Inc., November 28, 1994, 276 pp., \$22.95, 0-89526-483-8.

Trees \& People: Forestland Ecosystems and Our Future dispels the notion that today's Forest Products Industry is the vil- lain in the struggle to preserve and nurture our forestlands. Jordan exposes the absurdity of a for-profit industry bent on destroying its own livelihood! Acknowledging abuses of the nineteenth century, including clearcutting in arid regions and lack of replanting, Jordan cites the recent record of the Forest Products Industry; the "supply miracle" of meeting an exponential increase in demand for wood products while adapting to a dramatic decrease in forestland available for intensive ecosystem management. The fact remains that with the tremendous increase in yield. "67 percent of our original colonial forestlands are still intact."

Jordan argues that arbitrary designation of areas as wilderness, and the avalanche of species listed as "endangered," preclude the ecosystem management that our forestlands critically need. This neglect has left "old growth" forests at the mercy of insects, rot, and disease, to become barren tracts of wasted potential. He writes, "One of the more prevalent and misleading notions is that wildlife and plants are more abundant in old growth than in managed forestland ecosystems. There is no reliable data to support this contention. In fact, where serious research has been undertaken, the reverse seems to be the case." Jordan shows that rather than being prime habitat for wildlife, old growth forests are largely dangerous tinder boxes, "sick ecosystems" devoid of vigorous life. These untended forest areas are the most susceptible to wildfire, which indiscriminately destroys property, homes, and human life, along with valuable timber.

Trees \& People is a clarion call for the resumption of dialogue between groups falsely dichotomized by the media. Common ground exists between loggers and environmentalists because both groups have the same goal - to preserve one of our most precious renewable resources. Jordan marshals evidence refuting the demonization of "clearcutting," and emphasizes the "inherent characteristics" of forestland ecosystems. They are "renewable resources" that are "resilient, dynamic, changeable, and changing." Jordan writes, "For the temperate marine forestlands along the Pacific Ocean and for much of the Southern pine region, current science and technology indicate that the widely used practice of clearcutting is the best prescription for renewing forestland ecosystems."
Canadian Foreign Policy: Principles and Priorities for the Future. Report of the Special Joint Committee of the Senate and the House of Commons. Government of Canada, Ottawa, Ontario. 1994. Available from: Canada Communications Group Publishing, Public Works and Government Services of Canada, Ottawa, Ontario K1A 0S9.

This report is of special interest to the forestry resources sector with reference to sustainable development. Some of the key recommendations follow:

The Committee believes that we need to maintain a proactive approach to sustainable development in our foreign policy. We recommend the following items be included on the foreign policy agenda:

(a) To strengthen the capacity of bilateral, regional and multilateral institutions to address sustainable development, and to make these institutions more efficient and accountable.

(b) To strengthen the linkage between trade and sustainable development through the World Trade Organization. We are confident that clear international standards and accepted rules can make a significant contribution to sustainable development while minimizing the current tendency to use the environment as an excuse to erect protectionist trade barriers. The International Institute for Sustainable Development has produced a useful set of principles to guide further work in this area.

(c) To foster mechanisms to ensure the close coordination of domestic and international policies on sustainable development, including the development of action-oriented consultative mechanisms with stakeholders.

(d) To accord priority status to the implementation of the environmental industries strategy.

(e) To pursue the sustainable development agenda agreed at the Earth Summit in Rio, including the implementation of global environment conventions and the development of further agreements related to forestry, fisheries and the circumpolar region.

(f) To ensure that relevant foreign policies are assessed for their potential impact on sustainable development.

(g) To address the linkages between sustainable development, poverty, democracy and governance. 